\title{
Androgen insensitivity syndrome: ten years of our experience
}

\section{Amudha Subramaniam ${ }^{1}$, Rajender Singh $^{2}$, Preetha Tilak ${ }^{1}$, Rema Devi ${ }^{1}$, Mahalingam Kulandaivelu ${ }^{3}$, Thangaraj} Kumarasamy $^{4}$

${ }^{I}$ Division of Human Genetics, St. John's Medical College, Bangalore, India, ${ }^{2}$ Central Drug Research Institute (Council of Scientific and Industrial Research), Lucknow, India ${ }^{3}$ Vellore Institute of Technology, Vellore University, Vellore, India, ${ }^{4}$ Center of Cellular and Molecular Biology (Council of Scientific and Industrial Research), Hyderabad, India

\section{TABLE OF CONTENTS}

\section{Abstract}

2. Introduction

3. Late presentation of AIS cases in India

4. Suggested routine investigation to identify AIS cases

5. Mutations in the AR gene

6. Identification of the mutational hot spots

7. Risk of gonadal cancer in AIS

8. Conclusion and suggestions

9. Acknowledgement

10. References

\section{ABSTRACT}

Abnormalities of secondary sexual differentiation manifest in varying degrees depending upon the severity of the underlying cause. Primary amenorrhea in phenotypic females is caused by several different factors, including hormonal imbalance, nutritional deficiency and sex differentiation abnormalities. Androgen insensitivity syndrome (AIS) accounts for a large proportion of such cases in phenotypic females but genetically male individuals. Over the past 10 years, we have collected data related to androgen insensitivity from more than 150 cases. The research identified several important but neglected facts about this syndrome; including the identification of mutations in $39 \%$ of the cases and the establishment of the cause of pathogenesis in $60 \%$ of them. The most intriguing facts were uncovered in relation to late presentation of the AIS cases, little awareness among patients and family members, no consensus on the age of performing gonadectomy, and reluctance of the patients to undergo recommended surgery. These issues need immediate attention to improve healthcare and management of AIS cases. This article summarizes our observations about AIS with an aim to spread awareness among patients and clinicians.

\section{INTRODUCTION}

$\begin{array}{ccc}\text { Secondary } & \text { sexual differentiation in males is } \\ \text { executed by } & \text { androgens (testosterone and }\end{array}$ dihydrotestosterone) during the prenatal stage. The messages of both testosterone and dihydrotestosterone are conveyed through androgen receptors (AR). The receptortestosterone complex signals differentiation of the Wolffian duct during embryonic life, regulation of secretion of the luteinizing hormone by hypothalamic-pituitary axis, and spermatogenesis. The receptor-dihydrotestosterone complex promotes the development of external genitalia and prostate during embryogenesis, and is also responsible for changes that occur at puberty in males (1). Apart from cytogenetic abnormalities, mutations in several different genes have been identified to cause abnormal secondary sexual differentiation in males. Androgen insensitivity syndrome (AIS) accounts for almost half of such cases $(2,3)$ and about $10 \%$ of cases referred for primary amenorrhea (4). The estimated incidence of AIS is 2-5 per 100,000 live births (5). The pathogenesis of the disorder is the inability of cells to respond to testosterone, resulting in the developmental failure of secondary sexual organs in males and sexual characteristics in genetically male individuals $(46, X Y)$. To date, mutations only in the 
androgen receptor $(A R)$ gene have been identified to cause AIS. The AR gene has been mapped on Xq11-12 (6) and encodes for a receptor protein of 919 amino acids. The androgen receptor belongs to a super-family of nuclear receptors for steroid hormones (7). Like other members of the steroid receptor super family, AR has three functional domains: a N-terminal transactivation domain, a DNAbinding domain, and a ligand /androgen binding domain (8). Mutations in the $A R$ gene cause androgen insensitivity syndrome (AIS) by impairing androgen-dependent male sexual differentiation (5). Several mutations across the entire coding region of the AR gene have been identified and are compiled in a database at the McGill University (9).

The degree of the loss of androgen function determines the severity of AIS phenotype. Total loss of function mutations cause complete androgen insensitivity syndrome (CAIS), characterized by female external genitals and phenotype with normal breast development, but sparingly developed or completely absent axillary and pubic hair. Mullerian derivatives such as the uterus and ovaries are usually absent, hence they have blind ending vaginal orifices $(10,11)$. In partial androgen insensitivity syndrome (PAIS), several different phenotypes could result depending on the extent of loss of AR function. The predominant female phenotype (female external genitalia, pubic hair with or without clitoromegaly and partially to completely fused labia) characterizes the most severe form, while less severe forms include ambiguous genitalia to predominantly male phenotype with micropenis, perineal hypospadias and cryptorchidism (12). The latter group of patients is also termed as Reifenstein syndrome. PAIS patients can be assigned a grade on a phenotypic scale according to affinity of the phenotype with male or female pattern. Individuals with mild form of androgen insensitivity (MAIS) usually have normal male genitals and internal male structures, and mildest forms may go unnoticed. During puberty, MAIS individuals may have breast enlargement, sparse facial and body hair, and small penis (13). Some affected males may also have impaired sperm production, resulting in oligozoospermia or azoospermia (14).

The research presented herein, was initiated approximately 10 years ago, and to-date has investigated more than 150 cases from different parts of India. In addition to identification of pathogenic mutations, careful analysis of clinical data has uncovered important but neglected issues, affecting the management of such cases. In this article, we provide a brief overview of the mutations identified and related facts such as late presentation, diagnosis, family awareness and response during management of the disorder.

\section{LATE PRESENTATION OF AIS CASES IN INDIA}

Onset of menstruation in India generally occurs sometime between 10 and 16 years of age. As expected, the age distribution of the girls achieving menarche would be normal. Delayed menarche beyond the $16^{\text {th }}$ year may be indicative of an underlying problem, and with every passing year, chances of an underlying physiological complication increase. The identification of the underlying problem in a timely manner could bring forward possible opportunities that could help normalize the AR function partially or fully, depending upon the complexity of the problem. However, the general population in India does not take the matter as seriously as it could consequently emerge out to be. There could be several factors behind this; the first and foremost being little awareness about AIS. Issues related to the onset of menarche and menstrual cycle are still considered taboo in several societies, and the discussion of the associated problems is generally restricted to women. Further, the importance of onset of menarche and regular menstruation is not clear to a significant number of women of reproductive age. The failure/delay of menarche or highly irregular menstruation is not understood to be the indicator of possible infertility.

We observed that the presentation is more delayed in the cases of complete androgen insensitivity where the external genitalia are indistinguishable from normal females. Throughout the study, the earliest presentation of any CAIS case (family approaching clinic) at the age of 17 years and latest by the age of 35 years, with an average age at presentation of 22 years, was observed. Considering 13 years to be the average age of achieving menarche, the presentation of such cases is delayed by an average of nine years. The only cases of early presentation are those with abnormal external genitalia which draws early attention from the family. For example, a four year old child was referred for karyotyping with chief complaint of sexual ambiguity. The child was $2^{\text {nd }}$ born to a consanguineous couple in an uncle-niece union. Clinical investigation showed cranio-stenosis in the child, inguinal hernia was absent, external genitals were ambiguous with clitoromegaly and labio-scrotal fusion. Ultrasonography revealed absent uterus and ovaries. Bilateral gonads were palpable in the inguinal region. Gonadal biopsy showed bilateral gonads with testicular tissue. The phenotype was concordant with PAIS. Molecular analysis on this case revealed a single nucleotide deletion at 2616 in exon four of the AR gene, resulting in a frame-shift beyond amino acid 696, ultimately introducing a stop codon at 787 .

To the worst extent, several such cases which presented with clinically normal looking external genitalia are never presented to the clinic. This research came across some cases who got married and presented themselves to the clinic at a much later age when they failed to conceive. It is quintessential to present such cases to the clinic at a younger age, preferably immediately after failure of menarche onset in the teenage. Failure of menarche onset could be because of various possible underlying factors. We have now accumulated enough information about possible causes of failure of menarche. Therefore, sequential and detailed examination of the patients could lead to the identification of possible cause of the abnormality. Many such cases could be easily managed either by hormone therapy or by minor surgical procedures. In cases with underlying genetic defects, such as that of AIS, external genitalia could be surgically constructed to replicate normal female/male genitalia depending upon the 
pattern of appearance. Particularly in CAIS, external genitalia are indistinguishable from normal females. It is almost impossible to differentiate these cases from their normal counterparts by physical examination. The only externally visible difference lies in the absent/scanty pubic and axillary hair, but this is true only for CAIS. In many cases of PAIS, the presentation of normal looking external genitalia with appropriate development of public and axillary hair could further delay clinical presentation.

\section{SUGGESTED ROUTINE INVESTIGATION TO IDENTIFY AIS CASES}

The first step in early detection is physical examination of the subjects. The patients should be examined thoroughly for physical appearance, development of pubic and axillary hair, breast development and external genitalia. A significant delay in development of secondary sexual characters beyond $16^{\text {th }}$ year could indicate AIS. Ultrasound is recommended for further examination of the pelvis for detection of internal reproductive organs such as the presence of a hypoplastic/rudimentary uterus, abdominal gonads etc. The vagina in these cases is not longer than $6-7 \mathrm{~cm}$ and ends blindly. Phenotypic affinity to any degree of androgen insensitivity should be taken into account to make preliminary diagnosis (15). Peripheral levels of testosterone, LH and FSH would help find if there is masculine/elevated level of testosterone. Products of absolute values of testosterone and LH have been named as androgen sensitivity index (ASI). Elevated values of ASI could indicate possible insensitivity to androgens. Karyotype analysis should be performed to rule out cytogenetic abnormalities and confirm chromosome complement before further molecular investigations. Artifacts in the AR gene are the most common cause of AIS. Therefore, sequence analysis of the AR gene should be the first molecular target. Research over the last few decades has helped identify mutations in a large number of these cases. Though the identification of a mutation in the AR gene confirms androgen insensitivity, inability to identify such a mutation does not rule out the possibility of AIS. These cases could be further investigated for mutations in other candidate genes such as 17hydroxylase and 5- $\alpha$-reductase or AR co-regulators; however, mutations in these are not commonly seen.

\section{MUTATIONS IN THE AR GENE}

A large number of mutations have been identified in the AR gene and are documented at the AR mutation database $(9,16)$ (web: http://www.mcgill.ca/androgendb/). Of these, approximately $90 \%$ has been reported in androgen insensitivity. A significant number of these mutations have been supported by functional assays to compromise ligandbinding and/or transactivation potential of the mutant receptor molecule. Most of the mutations resulting in androgen insensitivity are the substitutions along with a low frequency of deletions/insertions. Structural-functional correlation of these mutations is now possible due to availability of crystal structure of AR-LBD and ligand-binding/transactivation data for a large number of mutations (17).

Although almost every kind of mutation has been reported throughout the AR gene, it has been attempted to make certain generalizations (16). Insertions and deletions could result in the insertion of premature termination codon within the open reading frame of the AR. In different pedigrees, such mutations have been localized to each of the eight exons of the AR gene and associated most often with CAIS (18). Mutations causing loss of androgen binding and transactivation function represent another relatively homogenous class of defects. Nucleotide sequencing in such patients has identified mutations causing a broad range of androgen resistant phenotypes including CAIS and PAIS (18). Mutations that disrupt $\mathrm{N}$ and $\mathrm{C}$-terminal interactions of the $\mathrm{AR}$ protein form another category of mutations, which retain normal ligand-binding (19). Mutations causing qualitative abnormalities of ligand-binding such as alterations of ligand affinity, thermal instability of ligand-binding and rapid dissociation of ligand from the receptor protein, constitute another category. These mutations also associate with the entire range of androgen-resistant phenotypes $(16,20)$.

It has also been attempted to find correlations between the site of mutation in secondary structure of the AR protein and androgen insensitivity phenotype. Most of the mutations in $\alpha$ helical and $\beta$ sheet regions of the receptor result in CAIS and those in turns and linker regions result in PAIS. Supporting this, our study on a familial CAIS case revealed L859F mutation in helix 10 of the AR protein (21). However, a general correlation is difficult to derive because some mutations in the helices and $\beta$ sheet regions associate with PAIS and those in turns and linker regions have been observed in CAIS $(7,16)$. Identification of new mutations could help make more appropriate generalizations between the site of mutation, secondary structure, and the AIS phenotype.

\section{IDENTIFICATION OF THE MUTATIONAL HOT SPOTS}

Research worldwide has reported about 500 mutations in the AR gene and about 1000 patients have been either analyzed or presented with AR mutations (AR mutation database) $(9,16)$. Our research on AIS over the last decade has investigated more than 150 cases of androgen insensitivity. Most of these cases were subjected to direct sequencing of the AR gene. We have successfully identified AR mutations in a large number (about 39\%) of such cases. Wherever available, samples of other family members were also analyzed for identification of the pathogenic mutation (22-26). Therefore, the molecular diagnosis of AIS has now been well established.

We have published several such mutations in a case series (22-26, Table 1). AR mutation database is hosted at the McGill University and is regularly updated for newly identified mutations. This has not only helped cataloging of the AR mutations, but also in identification of mutational hot-spots of the AR gene. Though today the phenotypic features of this syndrome are well known and hundreds of mutations along with their pathogenic mechanisms have been identified, analysis of new cases could still be equally interesting. This could help in identifying mutational hot spots, thus quickening molecular diagnosis by preferential analysis of selected spots. Molecular investigations on new mutations would further help understand the biological significance of each amino acid residue of this protein. 
Table 1. Some of representative cases of AIS with pathogenic mutations

\begin{tabular}{|c|c|c|c|c|c|c|c|}
\hline $\begin{array}{l}\text { Case } \\
\text { No. }\end{array}$ & Mutation & $\begin{array}{l}\text { AR } \\
\text { exon }\end{array}$ & AR domain & Manifestation & Phenotypic features & Age & Reference \\
\hline 01 & $\begin{array}{l}\text { C2578T } \\
\text { (L859F) }\end{array}$ & 7 & LBD & CAIS & $\begin{array}{l}\text { Typical female phenotype with female external genitalia, a short } \\
\text { blind ending vagina, breast development, and scanty axillary and } \\
\text { pubic hair. Real time ultrasonography of pelvis showed no } \\
\text { development of Wolffian duct derived structures, well distended } \\
\text { urinary bladder with no calculi and postvoid residue, no uterus } \\
\text { and mass lesions in pelvis. }\end{array}$ & 20 & (22) \\
\hline 02 & $\begin{array}{l}\text { C1760A } \\
\text { (Ala586Asp) }\end{array}$ & 2 & DBD & CAIS & $\begin{array}{l}\text { Well-developed breasts, female external genitals, blind ending } \\
\text { vagina, no pubic or axillary hair. Body fat deposition was in } \\
\text { typical female fashion but the patient had atypically higher body } \\
\text { weight. Pelvic ultrasound showed well distended urinary } \\
\text { bladder, uterus normal in size, abdominal gonads, small nodule } \\
\text { on left testis, small cyst on right testis and no development of } \\
\text { Wolffian duct derived structures. }\end{array}$ & 22 & (23) \\
\hline 03 & $\begin{array}{l}2329 \mathrm{G}>\mathrm{C} \\
(\mathrm{C} 601 \mathrm{~S})\end{array}$ & 3 & LBD & PAIS & $\begin{array}{l}\text { Poorly developed breasts, ambiguous genitalia with a small } \\
(1 \mathrm{~cm}) \text { phallus/penis like structure between the partially } \\
\text { developed labial folds, separate vaginal and urethral openings, } \\
\text { normal pubic and axillary hair. Ultrasound followed by } \\
\text { laparoscopic surgery of the pelvic region revealed rudimentary } \\
\text { uterus, no fallopian tubes, normal and well distended urinary } \\
\text { bladder, abdominal gonads and no mass lesion in pelvis. }\end{array}$ & 16 & (24) \\
\hline 04 & $\begin{array}{l}2650 \mathrm{G}>\mathrm{A} \\
(\mathrm{G} 708 \mathrm{E})\end{array}$ & 4 & LBD & CAIS & $\begin{array}{l}\text { Poorly developed breasts, female external genitals, blind ending } \\
\text { vagina and no pubic or axillary hair, consistent with complete } \\
\text { androgen insensitivity syndrome. Pelvic ultrasound showed no } \\
\text { development of Wolffian duct derived structures, well distended } \\
\text { urinary bladder, abdominal gonads, no uterus and presence of } \\
\text { cyst in the right gonad }\end{array}$ & 24 & $(25)$ \\
\hline 05 & $\begin{array}{l}2205 \mathrm{C}>\mathrm{A} \\
(\mathrm{Arg} 615 \mathrm{Ser})\end{array}$ & 3 & DBD & CAIS & $\begin{array}{l}\text { Female external genitals, blind ending vagina and no/scanty } \\
\text { pubic or axillary hair. Pelvic ultrasound showed no development } \\
\text { of Wolffian duct derived structures, no uterus, and presence of } \\
\text { well distended urinary bladder and abdominal gonads. }\end{array}$ & - & (26) \\
\hline 06 & $\begin{array}{l}2616 \text { TT } \Delta \mathrm{TG} \\
\text { (Del) causing } \\
\text { frame shift } \\
\text { followed by } \\
\text { stop codon at } \\
\text { position } 787\end{array}$ & 4 & LBD & PAIS & $\begin{array}{l}\text { Medical condition showed cranio-stenosis in the child. Inguinal } \\
\text { hernia was absent, external genitals were ambiguous with } \\
\text { clitoromegaly and labio-scrotal fusion. Ultrasonography } \\
\text { revealed absent uterus and ovaries. Bilateral gonads were } \\
\text { palpable in the inguinal region. }\end{array}$ & 4 & $\begin{array}{l}\text { Present } \\
\text { study }\end{array}$ \\
\hline 07 & $\begin{array}{l}2754 \mathrm{G}>\mathrm{A} \\
(\mathrm{Gly} 743 \mathrm{Glu})\end{array}$ & 5 & LBD & CAIS & $\begin{array}{l}\text { Female external genitalia, blind ending vagina, abdominal testis, } \\
\text { normal breast development and no pubic or axillary hair. }\end{array}$ & 18 & $\begin{array}{l}\text { Present } \\
\text { study }\end{array}$ \\
\hline 08 & $\begin{array}{l}2781 \mathrm{G}>\mathrm{A} \\
(\mathrm{Arg} 752 \mathrm{Gln})\end{array}$ & 5 & LBD & CAIS & $\begin{array}{l}\text { The patient was a normal built female with no hirsutism, having } \\
\text { female voice, scanty axillary and pubic hair growth and normal } \\
\text { breast development. The patient had smooth skin texture, } \\
\text { gynecoid pelvis and female genitalia. Ultrasound findings } \\
\text { suggested an infantile uterus and abdominal testis. }\end{array}$ & 15 & $\begin{array}{l}\text { Present } \\
\text { study }\end{array}$ \\
\hline 09 & $\begin{array}{l}2821 \\
\text { CCC } \Delta \mathrm{TG} \\
(\mathrm{Del} 766)\end{array}$ & 5 & LBD & CAIS & $\begin{array}{l}\text { The individual had a normal built with no hirsutism, female } \\
\text { voice but absent axillary and pubic hair. The patient had a height } \\
\text { of } 154 \mathrm{~cm} \text {, weight of } 42 \mathrm{~kg} \text {, asymmetric breast development } \\
\text { with normal development of right side and no development of } \\
\text { left breast. Skin texture was smooth, hyper-pigmentation was } \\
\text { observed over the chest, sternal region, extending to the breast } \\
\text { and back side of the ear. Pelvis was gynecoid, external genitalia } \\
\text { were female with prominent labia majora and non-prominent } \\
\text { labia minora. On per-vaginal-examination, uterus was not felt } \\
\text { and gonads were not palpable and vaginal orifice was blind } \\
\text { ending. Ultrasound findings revealed absent or non-visualized } \\
\text { uterus. }\end{array}$ & 20 & $\begin{array}{l}\text { Present } \\
\text { study }\end{array}$ \\
\hline 10 & $\begin{array}{l}2894 \mathrm{C}>\mathrm{G} \\
\text { (Leu790Leu) }\end{array}$ & 6 & LBD & CAIS & $\begin{array}{l}\text { The patient had affinity to typical female phenotype with female } \\
\text { voice, no hirsutism, scanty axillary and pubic hair but no breast } \\
\text { development. Pelvis was gynecoid, external genitalia appeared } \\
\text { to be normal; ultra sound finding suggested absent or non- } \\
\text { visualized uterus and the presence of abdominal testis. }\end{array}$ & 16 & $\begin{array}{l}\text { Present } \\
\text { study }\end{array}$ \\
\hline
\end{tabular}

\section{RISK OF GONADAL CANCER IN AIS}

It has been found that abdominal gonads in the AIS are prone to increased cancer risk. Fortunately, the risk of gonadal malignancy in AIS cases is relatively lower in comparison to other disorders of gonadal differentiation and sexual development. In addition, gonadal malignancy in these patients occurs at a much later stage in comparison to other such disorders. Typically, patients older than 30 years are at a greater risk of cancer. Among our patients having malignancy, 8 out of 10 were over 30 years of age. It is difficult to estimate the cancer risk in these patients. Dewhurst found no malignancy in 82 patients and estimated the risk to be approximately 5\% (27). However, Morris and Mahesh reported a much higher $(22 \%)$ risk of gonadal cancer in 181 AIS patients (28). Most of the malignancies were of germ cell origin. Manuel et al. (1976) analyzed a series of 23 patients with Dewhurst series and reported that expectancy of tumors is $3.6 \%$ at the age of 25 and $33 \%$ at the age of 50 (29). Therefore, the risk of malignancy rises exponentially with age, making late presentation highly risky. Gonadectomy is suggested to eliminate cancer risk. It has been debated whether 
gonadectomy should be performed before or after puberty. Many authors believe this to be a relatively low incidence which allows for safe postponement of gonadectomy after puberty. In one study conducted on 12 patients with AIS, gonadal biopsy was performed to investigate whether carcinomatous changes could be seen in children; three of 12 patients had intratubular neoplasia, which was considered premalignant (30). Carcinoma in situ was diagnosed in the testes of three of eight consecutive patients with AIS at two months and at 13 and 14 years. The authors concluded that testicular biopsy is warranted as soon as the syndrome is diagnosed and that finding of in situ seminoma should indicate immediate orchidectomy. Most authors suggest that at least one gonad be left until puberty to allow for the endogenous estrogen to result in secondary sex characteristics (31). In most of the studies, no seminoma had developed by the age of puberty.

In our experience with Indian patients, no case of seminoma was seen before the age of 22 years, suggesting that it may be safe to allow pubertal changes in these patients before the gonads are surgically excised; however, late presentation of such cases could lead to development of seminoma. As mentioned above, most of our patients with seminoma were above the age of 30 years. Therefore, early presentation of these cases is strictly advised and gonadectomy should be considered, if not earlier immediately after puberty. As suggested, it may be beneficial to retain gonads up to puberty to let pubertal changes happen; however, continued presence of the abdominal gonads (often testes), results in excess amount of unused testosterone, which now gets converted to estradiol, resulting in estrogenic effects on the body. Apart from excessive breast growth in a significant number of cases, unusual weight gain in some cases could be one of the consequences of high estradiol level. Nevertheless, continued risk of cancer due to excessive estradiol is equally dangerous. Therefore, it is not only the time of presentation of the case which matters, but also the time of gonad excision. In a significant number of the cases where we suggested gonadectomy, the patients did not turn back, putting themselves at a high risk of malignancy.

\section{CONCLUSION AND SUGGESTIONS}

In brief, the characterization of AIS phenotype is now routine and cases can be easily identified following a standard screening procedure. Molecular diagnosis of the cases should begin with analysis of the AR gene, which accounts for the abnormality in highest number of such cases. Failure to identify pathogenic mutations in the AR gene could be the basis to screen other candidate genes. Upon identification of androgen insensitivity, gonadectomy should be performed as early as possible, preferably immediately after puberty. Other female members of the family should also be screened for identification of similar features and underlying molecular defects so that genetic counseling could be provided to the family. One of the main aims of this article is to spread awareness among patients and family members so that early presentation and appropriate management of the disorder is facilitated.

\section{ACKNOWLEDGEMENT}

First and foremost we are grateful to the patients and family members for participating in the study. We would also like to thank staffs of the Division of Human Genetics St. John's Medical College Bangalore and team members at Centre of Cellular and Molecular Biology, Hyderabad, for their support during the course of this research work. Thanks to Monica Marie Grey for help in finishing this article.

\section{REFERENCES}

1. Haqq CM, PK Donahoe: Regulation of sexual dimorphism in mammals. Physiol Rev 78, 1-33 (1998)

2. Wilhelm D, P Koopman: The makings of maleness: towards an integrated view of male sexual development. Nat Rev Genet 7, 620-631 (2006)

3. Wilhelm D, S Palmer, P Koopman: Sex determination and gonadal development in mammals. Physiol Rev 87, $1-28(2007)$

4. Imperato-McGinley J, M Pichardo, T Gautier, D Voyer, M P Bryden: Cognitive abilities in androgeninsensitive subjects: comparison with control males and females from the same kindred. Clin Endocrinol 34, 341-353 (1991)

5. Grumbach MM, FA Conte. Disorders of sex differentiation. In: William's Textbook of Endocrinology, Eds: JD Wilson, DW Foster, HM Kronenberg, and PR Larsen, Philadelphia (1998)

6. Lubahn DB, DR Joseph, PM Sullivan, HF Willard, FS French, EM Wilson: Cloning of human androgen receptor complementary DNA and localization to the X chromosome. Science 240, 327-330 (1988)

7. Evans RM: The steroid and Thyroid hormone receptor superfamily. Science 240, 889-894 (1988)

8. Yong EL, TG Tut, FJ Ghadessy, G Prins, SS Ratnam: Partial androgen insensitivity and correlations with the predicted three dimensional structure of the androgen receptor ligand-binding domain. Mol Cell Endocrinol 137, 41-50 (1998)

9. The Androgen Receptor Mutation Database. Website: (http://androgendb.mcgill.ca/). Accessed on April 14, 2012 .

10. Simpson JL, Elias S. In: Genetics in Obstetrics and Gynecology, $3^{\text {rd }}$ edition. Saunders, USA. 311-312 (2003) 11. Rimoin AL, JM Connor, RE Pyeritz, BR Korf. In: Principles \& Practice of Medical Genetics. $5^{\text {th }}$ edition. Churchill Livingstone, Elsevier, Philadelphia, USA 2065-2066 (2007)

12. Quigley CA, A de-Bellis, KB Marschke, E el-Awady, EM Wilson, FS French: Androgen Receptor Defects: 
Historical, Clinical, and Molecular Perspectives. Endocr Rev 16, 271-321 (1995)

13. Tsukada T, M Inoue, S Tachibana, Y Nakai, H Takebe: An androgen receptor mutation causing androgen resistance in undervirilized male syndrome. J Clin Endocrinol Metab 79, 1202-1207 (1994)

14. Yong EL, LS Lim, Q Wang, A Mifsud, J Lim, Y C Ong, KS Sim: Androgen receptor polymorphisms and mutations in male infertility. $J$ Endocrinol Invest 23, 573577 (2000)

15. Rajender S, L Singh, K Thangaraj. Phenotypic heterogeneity of mutations in androgen receptor gene. Asian J Androl 9, 147-179 (2007)

16. Gottlieb B, L K Beitel, J H Wu, M Trifiro: The androgen receptor gene mutations database (ARDB): 2004 update Hum Mutat 23, 527-533 (2004)

17. Matias PM, P Donner, R Coelho, M Thomaz, C Peixoto, S Macedo , N Otto, S Joschko, P Scholz, A Wegg, S Basler M Schafer, U Egner, M A Carrondo : Structural evidence for ligand specificity in the binding domain of the human androgen receptor. Implications for pathogenic gene mutations. J Biol Chem 275, 26164-26171 (2000)

18. McPhaul MJ: Androgen receptor mutations and androgen insensitivity. Mol Cell Endocrinol 198, 61-67 (2002)

19. Langley E, JA Kemppainen, E M Wilson: Intermolecular NH2-/carboxyl-terminal interactions in androgen receptor dimerization revealed by mutations that cause androgen insensitivity. J Biol Chem 273, 92-101 (1998)

20. Grino PB, JE Griffin, WG Cushard, JD Wilson: A mutation of the androgen receptor associated with partial androgen resistance, familial gynecomastia, and fertility. $J$ Clin Endocr Metab 66, 754-761 (1988)

21. Singh R, PK Shastry, AA Rasalkar, L Singh, K Thangaraj: A novel androgen receptor mutation resulting in complete androgen insensitivity syndrome and bilateral Leydig cell hyperplasia. J Androl 27, 510-516 (2006)

22. Rajender S, L Singh, K Thangaraj: L859F mutation in androgen receptor gene results in complete loss of androgen binding to the receptor. $J$ Androl 28, 772-776 (2007)

23. Rajender S, NJ Gupta, B Chakrabarty, L Singh, K Thangaraj: Ala 586 Asp mutation in androgen receptor disrupts transactivation function without affecting androgen binding. Fertil Steril 91, 933.e23-28 (2009)

24. Singh R, P Singh, NJ Gupta, B Chakrabarty, L Singh, K Thangaraj: C601S mutation in the androgen receptor results in partial loss of androgen function. J Steroid Biochem Mol Biol 122, 359-363 (2010)

25. Rajender S, S Pooja, NJ Gupta, B Chakrabarty, L Singh, K Thangaraj: G708E mutation in the androgen receptor results in complete loss of androgen function. $J$ Androl 32, 193-198 (2011)

26. Sharma V, R Singh, K Thangaraj, A Jyothy: A novel Arg615Ser mutation of androgen receptor DNA-binding domain in three 46,XY sisters with complete androgen insensitivity syndrome and bilateral inguinal hernia. Fertil Steril 95, 804.e19-21 (2011)

27. Dewhurst CJ, HP Ferreire, PG Gillet: Gonadal malignancy in XY females. J Obstet Gynaecol Br Common 78, 1077-1083 (1971).

28. Morris J, V Mahesh: Further observations on the syndrome, "testicular feminization." Am J Obstet Gynecol 87, 731-733 (1963)

29. Manuel M, KP Katayama, HW Jr Jones: The age of occurrence of gonadal tumors in intersex patients with Y chromosome. Am J Obstet Gynecol 124, 293-300 (1976)

30. Muller J, N Skakkebaek : Testicular carcinoma in situ in children with the androgen insensitivity (testicular feminization) syndrome. $\mathrm{Br}$ Med $J$ 288, 1419-1420 (1984).

31. Silverstein AM, RT Jones: Testicular feminization syndrome with pelvic seminoma. J Ultrasound Med 7, 477479 (1988)

Key Words: Androgen Receptor, Androgen Insensitivity Syndrome, Sex Reversal, CAIS, review

Send correspondence to: Rajender Singh, Department of Endocrinology, Central Drug Research Institute, Division of Endocrinology, Central Drug Research Institute, Lucknow, U.P., India, Tel: 91-522-2613894, Fax: 91-5222623938, E- mail: rajender_singh@cdri.res.in 